\title{
The Relationship between the progression of colorectal cancer and microRNA polymorphisms
}

\section{대장암의 진행과 microRNA 유전자 다양성과의 관계}

\section{Department of Surgery, 'Institute for Clinical Research,, School of Medicine, CHA University, Seongnam, South Korea Ho Jin Chang, Nam Keun Kim', Young Joo Jeon', Jong Woo Kim}

차 의과학 대학교, 외과학 교실 장호진, 김종우, 임상연구소 김남근, 전영주

\section{초 록}

연구목적 : 최근 miRNA는 기본적인 생물학적 과정 뿐만 아니라 암을 포함한 다양한 질환의 조절기능에도 관여하는 것으로 알려 져 있다. 비록 적은 수의 nucleotides(18 23)로 이루어진 noncoding RNA이지만 miRNA의 유전자 내에서의 nucleotide 변 이(variation)은 miRNA의 성숙과정에 영향을 주어 궁극적으로 는 miRNA 발현을 변화시킬 수 있다. 따라서 본 연구에서는 지금 까지 암과 연관이 있는 것으로 알려져 있는 4 가지 miRNA의 유 전자 다양성을 분석하여 대장암의 진행 정도, 즉 암 병기, 암의 침윤도, 림프절 전이 등의 임상양상과 어느 정도 연관이 있는지 를 분석해 보았다.

대상과 방법 : 최근 만 2 년 동안 병원에서 수술 받은 대장암 환자 160 을 대상으로 혈액채취 후 DNA를 추출하여 $\mathrm{miR}-146 \mathrm{aC}>\mathrm{G}$, $\mathrm{miR}-149 \mathrm{~T}>\mathrm{C}, \mathrm{miR}-196 \mathrm{a} 2 \mathrm{~T}>\mathrm{C}$ 와 $\mathrm{miR}-499 \mathrm{~A}>\mathrm{G}$ 의 유전자 다양 성 분포를 $\mathrm{PCR}-\mathrm{RFLP}$ 로 분석하였다. 이 결과를 암의 진행 정도 와 관련 있는 병기, 조직학적 암의 분화도, 암의 장벽 침윤도, 국 소 림프절 전이 등에 따라 비교 분석하였다.

결과 : 먼저 환자들을 남(98예, $61.3 \%)$, 여(62예, 38.7\%)와 결장 (89예, 55.6\%), 직장(71예, 44.4\%)의 암 위치에 따라 4가지 miRNAs의 유전자 다양성에서 차이가 있는지를 분석해본 결과 의미 있는 차이를 보이지 않았다. 암의 진행과 연관이 있는 암의 병기 (I IV 기), 장벽 침윤도 ( $\mathrm{T} 1 \sim \mathrm{T} 4)$, 림프절 전이 정도 $(\mathrm{N} 0 \sim \mathrm{N} 2)$ 각각에 따라 4 가지 miRNAs 유전자 다양성의 차이를

책임저자 : 김종우

463-712, 경기도 성남시 분당구 야탑동 351 차의과학 대학교, 외과학 교실, 분당 차병원 Tel: 031-780-5250 Fax: 031-780-5259 E-mail: kjw@cha.ac.kr 접수일 : 2011년 9월 23일 ; 게재승인일 : 2011년 10월 20일
보았으나 의미가 없었다. 암의 분화도 (well-, moderately-, poorly-differentiated, mucinous)에 따라 분석을 해보았지만 역시 의미는 없었다.

결론 : 본 실험에서 선택한 4 가지 miRNA는 의미있는 결과를 보이지 않았지만 앞으로 보다 다양한 miRNA가 많이 연구되어 대장암과의 관계를 밝히도록 해야 할 것이다.

중심단어 : 마이크로 RNA, 유전자 다양성, 대장암

\section{서 론}

세포 핵 내에 DNA라는 유전자 물질이 발견되고, 그 구조가 밝혀 지고 또 이들 유전자로부터 발현(gene expression)의 일반적인 과정은 이미 밝혀져 있다. 즉, 우리는 유전정보를 함축하고 있는 $\mathrm{DNA}$ 로부터 mRNA, tRNA를 거쳐 아미노산의 이동에 의한 단백 합성이라는 고식적 단계만 있고 유전자 발현의 조절도 DNA에만 의존할 것으로 생각해 왔었다. 그러나 분자생물학의 발전에 의해 유전자 발현의 조절은 DNA 염기서열 자체 변화 뿐만 아니라 DNA methylation, histone acetylation 등의 그 주변의 변화 즉 후생학적 변화(epigenetic change)가 관여하여 하는 것이 밝혀졌 다. 따라서 유전학적인 현상은 그리 단순하지는 않고 우리의 생각 이상으로 복잡한 과정이라는 것이 기초과학이 발전함에 따라 밝 혀지고 있다. 최근에는 항상 DNA에 종속적이라고 생각되었던 $\mathrm{RNA}$ 들 중에 하찮은 부스러기(fragments)로 여겨졌던 아주 작은 RNA가 유전자 조절 및 역으로 DNA 유전자 발현에도 관여 한다 는 것이 밝혀졌고 이 들의 일부를 microRNA라고 명명하게 되었 다. 이 들 microRNA는 세포의 분화, 증식, 세포사멸(apoptosis), 
면역계, 대사, 발암 등 다양한 생명현상에 직, 간접적으로 관여한 다는 것이 알려져 있고 지금도 계속 활발히 연구 중이다. ${ }^{1-5)}$

MicroRNAs (miRNAs)는 작은 non-coding RNAs로 적은 수 (18 23)의 nucleotides를 지니고 유전자 발현을 조절하여 진핵 세포 (eukaryotic cell) 내에서의 다양한 생화학 과정에 관여한 다. miRNA 형성의 기본 과정은, 세포 핵 내에서 miRNA 유전 자는 RNA polymerase II에 의하여 전사되어 primary miRNA (pri-miRNA)로 되고, 이는 또 DGCR8-DROSHA complex에 의해서 premature miRNA (pre-miRNA)가 되며, Exportin-5 단백에 의해 세포질로 나와서 RNaseIII DICER에 의해 성숙한 miRNA가 된다. 이때 post-transcriptional regulator로서 miRNA는 target mRNA의 complementary sequences에 결합 해서 mRNA 소멸(degradation), 번역(translation) 또는 억제 (repression)를 일으키게 된다. ${ }^{6-8)}$

대장암은 국내에서 최근 급격히 증가하는 암으로 식생활 습관의 변화로 육류 및 과도한 칼로리의 섭취가 원인으로 생각된다. 활 발한 내시경 시술 등에도 불구하고 발병율 자체가 늘고 있어 보 다 낳은 예방 및 진단과 치료가 요구 된다. 따라서 이를 위해 대 장암 발암에 대한 기초적인 연구도 필수적이라고 할 수 있겠다. miRNA의 유전자 변이(mutations)에 따른 발현의 증가 및 감소 가 발암과 연관이 있다는 여러 연구들이 보고되고 있는데, Calin 등은 으슬 결손(deletions) 이 만성 림프구성 백혈병과 관련 이 있다고 처음 보고한 후, 폐암-10), B-cell 림프종1ㅣ , 유방암-2) 등에 서도 miRNA와의 관련성들이 보고되었다. 대장암과의 관련성은 Michael 등'13)이 처음 보고한 후 Schimanski 등는 은 miR-196a이 암세포의 진행과 관련이 있음을 보고하였다.

최근에는 microRNA의 DNA 유전자 다양성(polymorphism)에 의해 즉, miRNA의 single nucleotide polymorphisms (SNPs) 에 의해서도 최종 miRNA의 성질을 변화시켜 만성 질환이나 암 의 발생, 진행 및 예후와도 관련이 있다고 보고되고 있다. 예를 들면 중국인들에서 $\mathrm{Hu}$ 등하는 miR-196a2에서 CC 유전형 (genotype)은 폐암에 많고, CT 유전형은 의미 있게 간암하칯 뮈 암 ${ }^{17}$ 와 관련이 있다고 보고하였다. $\mathrm{miR}-146 \mathrm{aC}>\mathrm{G}, \mathrm{miR}-$ $149 \mathrm{CT}>\mathrm{C}$ 와 $\mathrm{miR}-499 \mathrm{~A}>\mathrm{G}$ 의 유전자 다양성은 유방암-18), 및 식 도암-1)과 관련이 있는 것으로 보고 되고 있다. 그러나 아직 대장 암에서의 microRNA 유전자 변이 및 다양성들의 역할은 많이 보 고되고 있지 않다. 따라서 본 연구의 목적은 지금까지 암과 연관 이 있는 것으로 알려져 있는 4 가지 $\mathrm{miR}-146 \mathrm{aC}>\mathrm{G}, \mathrm{miR}-$ $149 \mathrm{~T}>\mathrm{C}, \mathrm{miR}-196 \mathrm{a} 2 \mathrm{~T}>\mathrm{C}$, 및 $\mathrm{miR}-499 \mathrm{~A}>\mathrm{G}$ 의 유전자 다양성을
분석하여, 대장암의 병기, 암의 침윤도, 림프절 전이 등의 대장암 임상적 진행 정도와 연관이 있는지를 분석하였다.

\section{대상 및 방법}

최근 만 2 년 동안 병원에서 수술 받은 대장암 환자 160 을 대상 으로 하였다. 이들의 임상적 특징을 성별, 대장암의 위치와 병기 (The American Joint Committee on Cancer)에 따라 구분하였 고, 조직학적 소견에 따라 분화도, 장벽 침윤도, 국소 림프절 전 이 등으로 구분하였다. 환자에서 혈액을 채취하여 $\mathrm{DNA}$ 를 추출 하여 $\mathrm{miR}-146 \mathrm{aC}>\mathrm{G}, \mathrm{miR}-149 \mathrm{~T}>\mathrm{C}, \mathrm{miR}-196 \mathrm{a} 2 \mathrm{~T}>\mathrm{C}$ 와 $\mathrm{miR}-$ $499 \mathrm{~A}>\mathrm{G}$ 의 유전자 다양성을 PCR-RFLP로 분석하여 상기한 임 상적 소견들과 비교 분석하였다. 본 연구는 병원 내의 의료윤리 위원회로부터 연구 승인을 받았다.

\section{1. 유전자 분석}

DNA 는 혈액내의 백혈구로부터 G-dexTM II Genomic DNA Extraction Kit (iNtRON BIOTECHNOLOGY, Seongnam, South Korea)를 이용하여 추출하였다. $\mathrm{miR}-146 \mathrm{aC}>\mathrm{G}, \mathrm{miR}-$ $149 \mathrm{C}>\mathrm{T}, \mathrm{miR}-196 \mathrm{a} 2 \mathrm{C}>\mathrm{T}$ 와 $\mathrm{miR}-499 \mathrm{~A}>\mathrm{G}$ 의 유전자 다양성 (polymorphisms)은 polymerase chain reaction-restriction fragment length polymorphism (PCR-RFLP) assays 방법에 의해 분석하였다. 증폭을 위한 Primer의 유전자 서열은 다음과 같다 : $\mathrm{miR}-146 \mathrm{aC}>\mathrm{G}$ : forward $5^{\prime}$-CAT GGG TTG TGT CAG TGT CAG AGC T-3', backwards 5'-TGC CTT CTG TCT CCA GTC TTC CAA-3', miR-149C $>\mathrm{T}$ : forward 5'TGT CTT CAC TCC CGT GCT TGT CC-3', backwards 5' TGA GGC CCG AAA CAC CCG TA-3', miR-196a2C>T : forward 5'-CCC CTT CCC TTC TCC TCC AGA TA-3', backwards 5'-CGA AAA CCG ACT GAT GTA ACT CCG3'; miR-499A $>\mathrm{G}$ : forward 5'-CAA AGT CTT CAC TTC CCT GCC A-3', backwards 5'-GAT GTT TAA CTC CTC $\mathrm{TCC} \mathrm{ACG} \mathrm{TGA} \mathrm{TC}-3^{\prime}$. 냉각 온도는 $58^{\circ} \mathrm{C}$ 로 하였고, $\mathrm{miR}-$ 146a $\mathrm{C}>\mathrm{G}, \mathrm{miR}-149 \mathrm{~T}>\mathrm{C}$ 와 miR-196a2 $\mathrm{T}>\mathrm{C}$ polymorphisms 은 $37^{\circ} \mathrm{C}$ 에서 16 시간 동안 각각 $\mathrm{Sac} \mathrm{I}$, Alu I와 Msp I에 의해 추 출하였고, $499 \mathrm{~A}>\mathrm{G}$ polymorphism은 $50^{\circ} \mathrm{C}$ 에서 16 시간 동안 $\mathrm{Bcl}$ I (New England BioLabs, Beverly, MA, USA)에 의해서 추출 하였다. 반응 물질(12 $\mu \mathrm{l})$ 은 ethidium bromide로 염색된 3.0\% agarose ge을 따라 이동하게 하여 자외선 조사에 의해 직접적으 로 나타나게 하였다. 임의로 4 가지 miRNA 유전자 다양성 $\mathrm{PCR}$ 
assays의 약 $10 \%$ 정도는 반복실험을 하였으며 결과들은 automatic sequencer (ABI3730xl DNA Analyzer; Applied Biosystems, Foster City, CA, USA)를 이용하여 DNA 염기서 열에 의해 일치 여부를 검사하였다.

\section{2. 통계분석}

임상 요소들의 분석에는 Chi-square test와 Fisher' s exact test를 이용하였고, miRNA polymorphisms과의 연관성을 보기 위해서 multivariate logistic regression에 의한 $95 \%$ confidence intervals (95\% CIs)의 adjusted odds ratios $(\mathrm{AORS})$ 를 이용하였다. 통계학적 의의는 $\mathrm{P}<0.05$ 로 설정하였다.

\section{결 과}

\section{1. 대상환자들의 임상 및 조직학적 특성}

대상환자 160 예의 평균 연령은 $63.18 \pm 11.76$ 세였으며, 남자 98 예 (61.3\%), 여자 62예(38.7\%)였다. 대장암 중 결장암은 89예 (55.6\%), 직장암 71예(44.4\%)였다. 암의 병기는 I기 25 예 (15.6\%), II기 63예 (39.4\%), III기 53예 (33.1\%), IV기 19예 (11.9\%)의 분포였다. 암의 조직학적 분화도에 따라 고분화암 14 예(8.8\%), 중등도 분화암 128예 (80.0\%), 저분화암 6예 (3.8\%), 점액성암 12 예(7.5\%)였다. 조직학적 침윤도에 따라 $\mathrm{T} 1$ : 11 예 (6.9\%), T2: 19예(11.9\%), T3: 93예(58.1\%), T4: 37예(23.1\%)의 분포를 보였고, 국소 림프절 전이 정도에 따라 NO: 91예(56.9\%), N1: 37예(23.1\%), N2: 32예(20.0\%)였다 (Table 1).

\section{2. 환자들의 성별 및 암 위치에 따른 miRNA 유전자 다양성}

먼저 성별과 암의 위치에 따라 4가지 miRNA의 유전자 다양성에 차이가 있는지 보았으나 거의 차이가 없이 유사한 분포를 보였 다. 특이 할 점은 3 가지 $\mathrm{mRNA}$ 의 유전자 다양성은 열성동형 (recessive homozygous phenotype)이 모두 $10 \%$ 미만의 일반 적인 빈도를 보인데 반해 $\mathrm{miR}-196 \mathrm{a} 2 \mathrm{~T}>\mathrm{C}$ 의 변이형(CC) 만은 $20 \%$ 내외의 높은 빈도를 보였다 (Table 2).

\section{3. 암의 병기에 따른 miRNA 유전자 다양성}

대장암의 병기 I기 25예, II기 63예, III기 53예, IV기 19예의 진 행에 따른 4 가지 miRNA의 유전자 다양성의 분포를 분석하였 다. 결과는 병기에 차이 없이 모두 고른 유사한 분포를 보였다. 혹시 우성 유전자나 열성 유전자들의 조합에 따라 차이 있는지를 살펴보았으나 의미가 없었다 (Table 3).
Table 1. Clinical characteristics of cases $(n=160)$.

\begin{tabular}{|c|c|}
\hline Characteristics & $\mathrm{n}(\%)$ \\
\hline Age, mean $\pm S D$ in years & $63.18 \pm 11.76$ \\
\hline \multicolumn{2}{|l|}{ Gender } \\
\hline Male & $98(61.3)$ \\
\hline Female & $62(38.7)$ \\
\hline \multicolumn{2}{|l|}{ Primary cancer location } \\
\hline Colon & 89 (55.6) \\
\hline Rectum & $71(44.4)$ \\
\hline \multicolumn{2}{|l|}{ Stage } \\
\hline $0 / 1$ & 25 (15.6) \\
\hline$\|$ & $63(39.4)$ \\
\hline III & $53(33.1)$ \\
\hline IV & 19 (11.9) \\
\hline \multicolumn{2}{|l|}{ Histological differentiation } \\
\hline Well & $14(8.8)$ \\
\hline Moderately & $128(80.0)$ \\
\hline Poorly & $6(3.8)$ \\
\hline Mucinous & $12(7.5)$ \\
\hline \multicolumn{2}{|l|}{ Denth of Invasion } \\
\hline $\mathrm{T} 1$ & $11(6.9)$ \\
\hline T2 & 19 (11.9) \\
\hline T3 & $93(58.1)$ \\
\hline T4 & $37(23.1)$ \\
\hline \multicolumn{2}{|l|}{ Regional LN Metastasis } \\
\hline No & $91(56.9)$ \\
\hline N1 & $37(23.1)$ \\
\hline N2 & $32(20.0)$ \\
\hline
\end{tabular}

Table 2. Genotype frequencies of miRNA polymorphisms according to gender and tumor sites.

\begin{tabular}{lrrrrrr}
\hline Characteristics & $\begin{array}{r}\text { Male } \\
(\mathrm{n}=98)\end{array}$ & $\begin{array}{r}\text { Female } \\
(\mathrm{n}=62)\end{array}$ & $P^{*}$ & $\begin{array}{r}\text { Colon } \\
(\mathrm{n}=89)\end{array}$ & $\begin{array}{r}\text { Rectum } \\
(\mathrm{n}=71)\end{array}$ & $P^{*}$ \\
\hline miR-146aC>G & & & & & & \\
$\mathrm{CC}$ & $34(34.7)$ & $22(35.5)$ & 1.000 & $28(31.5)$ & $28(39.4)$ & 0.406 \\
$\mathrm{CG}$ & $55(56.1)$ & $32(51.6)$ & 0.627 & $50(56.2)$ & $37(52.1)$ & 0.635 \\
GG & $9(9.2)$ & $8(12.9)$ & 0.599 & $11(12.4)$ & $6(8.5)$ & 0.454 \\
miR-149T>C & & & & & & \\
TT & $49(50.0)$ & $24(38.7)$ & 0.193 & $38(42.7)$ & $35(49.3)$ & 0.428 \\
TC & $44(44.9)$ & $32(51.6)$ & 0.422 & $44(49.4)$ & $32(45.1)$ & 0.634 \\
CC & $5(5.1)$ & $6(9.7)$ & 0.340 & $7(7.9)$ & $4(5.6)$ & 0.756 \\
miR-196a2T>CC & & & & & & \\
TT & $25(25.5)$ & $20(32.3)$ & 0.372 & $28(31.5)$ & $17(23.9)$ & 0.377 \\
TC & $46(46.9)$ & $27(43.5)$ & 0.745 & $40(44.9)$ & $33(46.5)$ & 0.874 \\
CC & $27(27.6)$ & $15(24.2)$ & 0.714 & $21(23.6)$ & $21(29.6)$ & 0.470 \\
miR-499A>G & & & & & & \\
AA & $63(64.3)$ & $37(59.7)$ & 0.616 & $60(67.4)$ & $40(56.3)$ & 0.189 \\
AG & $33(33.7)$ & $25(40.3)$ & 0.404 & $27(30.3)$ & $31(43.7)$ & 0.099 \\
GG & $2(2.0)$ & $0(0.0)$ & 0.522 & $2(2.2)$ & $0(0.0)$ & 0.503 \\
\hline *Fisher's exact test. & & & & & &
\end{tabular}


Table 3. Genotype frequencies of miRNA polymorphisms according to tumor stages.

\begin{tabular}{|c|c|c|c|c|c|}
\hline Characteristics & $\begin{array}{l}\text { Stage I } \\
(n=25)\end{array}$ & $\begin{array}{l}\text { Stage II } \\
(n=63)\end{array}$ & $\begin{array}{l}\text { Stage III } \\
(n=53)\end{array}$ & $\begin{array}{c}\text { Stage IV } \\
(n=19)\end{array}$ & $P^{*}$ \\
\hline \multicolumn{6}{|l|}{$m i R-146 a C>G$} \\
\hline $\mathrm{CC}$ & $6(24.0)$ & 26 (41.3) & $16(30.2)$ & $8(42.1)$ & 0.337 \\
\hline CG & $16(64.0)$ & $28(44.4)$ & 33 (62.3) & $10(52.6)$ & 0.188 \\
\hline GG & $3(12.0)$ & $9(14.3)$ & $4(7.5)$ & $1(5.3)$ & 0.564 \\
\hline Dominant (CC vs. CG+GG) & & & & & 0.337 \\
\hline Recessive (CC+CG vs. GG) & & & & & 0.564 \\
\hline \multicolumn{6}{|l|}{ miR-149T>C } \\
\hline$\Pi$ & $16(64.0)$ & $24(38.1)$ & $23(43.4)$ & $10(52.6)$ & 0.150 \\
\hline TC & $8(32.0)$ & $32(50.8)$ & $28(52.8)$ & $8(42.1)$ & 0.320 \\
\hline $\mathrm{CC}$ & $1(4.0)$ & $7(11.1)$ & 2 (3.8) & $1(5.3)$ & 0.398 \\
\hline Dominant (TT vs. $T C+C C)$ & & & & & 0.150 \\
\hline Recessive (T+TC vs. CC) & & & & & 0.398 \\
\hline \multicolumn{6}{|l|}{$\operatorname{miR}-196 \mathrm{a} 2 \mathrm{~T}>\mathrm{C}$} \\
\hline$\Pi$ & $4(16.0)$ & 21 (33.3) & $14(26.4)$ & $6(31.6)$ & 0.415 \\
\hline TC & $17(68.0)$ & 25 (39.7) & $22(41.5)$ & $9(47.4)$ & 0.097 \\
\hline $\mathrm{CC}$ & $4(16.0)$ & $17(27.0)$ & $17(32.1)$ & $4(21.1)$ & 0.463 \\
\hline Dominant (TT vs. $T C+C C)$ & & & & & 0.415 \\
\hline Recessive (T+TC vs. CC) & & & & & 0.463 \\
\hline \multicolumn{6}{|l|}{$\operatorname{miR}-499 \mathrm{~A}>\mathrm{G}$} \\
\hline $\mathrm{AA}$ & $16(64.0)$ & $41(65.1)$ & 32 (60.4) & 11 (57.9) & 0.924 \\
\hline$A G$ & $9(36.0)$ & 21 (33.3) & $20(37.7)$ & $8(42.1)$ & 0.904 \\
\hline GG & $0(0.0)$ & $1(1.6)$ & $1(1.9)$ & $0(0.0)$ & 0.852 \\
\hline Dominant (AAvs. AG+GG) & & & & & 0.924 \\
\hline Recessive (AA+AG vs. GG) & & & & & 0.852 \\
\hline
\end{tabular}

Table 4. Genotype frequencies of miRNA polymorphisms according to differentiation.

\begin{tabular}{|c|c|c|c|c|c|}
\hline Characteristics & $\begin{array}{l}\text { Well } \\
(n=14)\end{array}$ & $\begin{array}{c}\text { Moderately } \\
\qquad(n=128)\end{array}$ & $\begin{array}{l}\text { Poorly } \\
(n=6)\end{array}$ & $\begin{array}{c}\text { Mucinous } \\
(n=12)\end{array}$ & $P^{*}$ \\
\hline \multicolumn{6}{|l|}{$\operatorname{miR}-146 a \mathrm{C}>\mathrm{G}$} \\
\hline $\mathrm{CC}$ & $6(42.9)$ & 44 (34.4) & $1(16.7)$ & $5(41.7)$ & 0.677 \\
\hline CG & $7(50.0)$ & 71 (55.5) & $5(83.3)$ & 4 (33.3) & 0.227 \\
\hline GG & $1(7.1)$ & $13(10.2)$ & $0(0.0)$ & $3(25.0)$ & 0.317 \\
\hline Dominant (CC vs. CG+GG) & & & & & 0.677 \\
\hline Recessive (CC+CG vs. GG) & & & & & 0.317 \\
\hline \multicolumn{6}{|l|}{ miR-149T>C } \\
\hline$\pi$ & $9(64.3)$ & $57(44.5)$ & $3(50.0)$ & $4(33.3)$ & 0.423 \\
\hline TC & $5(35.7)$ & $62(48.4)$ & $3(50.0)$ & $6(50.0)$ & 0.833 \\
\hline $\mathrm{CC}$ & $0(0.0)$ & $9(7.0)$ & $0(0.0)$ & $2(16.7)$ & 0.351 \\
\hline Dominant (TT vs. $\mathrm{TC}+\mathrm{CC}$ ) & & & & & 0.423 \\
\hline Recessive (T+TC vs. CC) & & & & & 0.351 \\
\hline \multicolumn{6}{|l|}{$\operatorname{miR}-196 \mathrm{a} 2 \mathrm{~T}>\mathrm{C}$} \\
\hline$\Pi$ & $1(7.1)$ & $41(32.0)$ & $1(16.7)$ & $2(16.7)$ & 0.159 \\
\hline TC & $8(57.1)$ & $53(41.4)$ & $5(83.3)$ & $7(58.3)$ & 0.117 \\
\hline $\mathrm{CC}$ & $5(35.7)$ & 34 (26.6) & $0(0.0)$ & $3(25.0)$ & 0.424 \\
\hline Dominant (TT vs. $\mathrm{TC}+\mathrm{CC}$ ) & & & & & 0.159 \\
\hline Recessive (T+TC vs. CC) & & & & & 0.424 \\
\hline \multicolumn{6}{|l|}{$\operatorname{miR}-499 \mathrm{~A}>\mathrm{G}$} \\
\hline $\mathrm{AA}$ & $10(71.4)$ & 79 (61.7) & $6(100.0)$ & $5(41.7)$ & 0.097 \\
\hline$A G$ & $4(28.6)$ & $7(36.7)$ & $0(0.0)$ & $7(58.3)$ & 0.097 \\
\hline GG & $0(0.0)$ & $2(1.6)$ & $0(0.0)$ & $0(0.0)$ & 0.918 \\
\hline Dominant (AAvs. AG+GG) & & & & & 0.097 \\
\hline Recessive (AA+AG vs. GG) & & & & & 0.918 \\
\hline
\end{tabular}

Table 5. Genotype frequencies of miRNA polymorphisms according to infiltration.

\begin{tabular}{|c|c|c|c|c|c|c|c|c|c|c|c|}
\hline Characteristics & $\begin{array}{c}\text { T1 } \\
(n=11)\end{array}$ & $\begin{array}{c}\text { T2 } \\
(n=19)\end{array}$ & $\begin{array}{c}\text { T3 } \\
(n=93)\end{array}$ & $\begin{array}{c}\text { T4 } \\
(n=37)\end{array}$ & $P^{*}$ & Characteristics & $\begin{array}{c}\text { T1 } \\
(n=11)\end{array}$ & $\begin{array}{c}\text { T2 } \\
(n=19)\end{array}$ & $\begin{array}{c}\text { T3 } \\
(n=93)\end{array}$ & $\begin{array}{c}\mathrm{T} 4 \\
(\mathrm{n}=37)\end{array}$ & $P^{*}$ \\
\hline$m i R-146 a C>G$ & & & & & & miR-196a2T $>C$ & & & & & \\
\hline $\mathrm{CC}$ & $3(27.3)$ & $6(31.6)$ & 31 (33.3) & $16(43.2)$ & 0.658 & $\Pi$ & $0(0.0)$ & $5(26.3)$ & 25 (26.9) & $15(40.5)$ & 0.065 \\
\hline CG & $6(54.5)$ & $12(63.2)$ & 49 (52.7) & $20(54.1)$ & 0.873 & $\mathrm{TC}$ & $7(63.6)$ & $12(63.2)$ & 38 (40.9) & $16(43.2)$ & 0.193 \\
\hline GG & $2(18.2)$ & $1(5.3)$ & $13(14.0)$ & $1(27.0)$ & 0.188 & $\mathrm{CC}$ & $4(36.4)$ & $2(10.5)$ & 30 (32.3) & $6(16.2)$ & 0.083 \\
\hline Dominant (CC vs. CG+GG) & & & & & 0.658 & Dominant $(T$ vs. $T C+C C)$ & & & & & 0.065 \\
\hline Recessive (CC+CG vs. GG) & & & & & 0.188 & Recessive (T+TC vs. CC) & & & & & 0.083 \\
\hline $\operatorname{miR}-149 \mathrm{~T}>\mathrm{C}$ & & & & & & $\operatorname{miR}-499 \mathrm{~A}>\mathrm{G}$ & & & & & \\
\hline$\pi$ & $7(63.6)$ & $11(57.9)$ & 39 (41.9) & $16(43.2)$ & 0.364 & $\mathrm{AA}$ & $6(54.5)$ & $11(57.9)$ & $56(60.2)$ & $27(73.0)$ & 0.492 \\
\hline TC & $3(27.3)$ & $8(42.1)$ & 46 (49.5) & 19 (51.4) & 0.496 & $A G$ & $5(45.5)$ & $8(42.1)$ & $36(38.7)$ & $9(24.3)$ & 0.361 \\
\hline $\mathrm{CC}$ & $1(9.1)$ & $0(0.0)$ & $8(8.6)$ & $2(5.4)$ & 0.563 & GG & $0(0.0)$ & $0(0.0)$ & $1(1.1)$ & $1(2.7)$ & 0.797 \\
\hline Dominant (TT vs. TC+CC) & & & & & 0.364 & Dominant (AAvs. $A G+G G$ ) & & & & & 0.492 \\
\hline Recessive (T+TC vs. CC) & & & & & 0.563 & Recessive (AA+AG vs. GG) & & & & & 0.797 \\
\hline
\end{tabular}

\section{4. 암의 분화도에 따른 miRNA 유전자 다양성}

고분화암 14 예, 중등도 분화암 128 예, 저분화암 6 예, 점액성 암
12 예에 따라 4가지 miRNA 유전자 다양성의 분포를 보았다. $\mathrm{miR}-196 \mathrm{a} 2 \mathrm{~T}>\mathrm{C}$ 에서 상대적으로 우성 동형 유전자 TT의 분포 
Table 6. Genotype frequencies of miRNA polymorphisms according to the number of lymph node metastasis.

\begin{tabular}{|c|c|c|c|c|}
\hline Characteristics & $\begin{array}{l}\text { None } \\
(n=91)\end{array}$ & $\begin{array}{l}1 \leq N<4 \\
(n=37)\end{array}$ & $\begin{array}{c}N \geq 4 \\
(n=32)\end{array}$ & $P^{*}$ \\
\hline \multicolumn{5}{|l|}{ miR-146aC>G } \\
\hline $\mathrm{CC}$ & 32 (35.2) & $11(29.7)$ & $13(40.6)$ & 0.638 \\
\hline CG & $46(50.5)$ & $23(62.2)$ & 18 (56.3) & 0.476 \\
\hline GG & $13(14.3)$ & $3(8.1)$ & $1(3.1)$ & 0.180 \\
\hline Dominant (CC vs. CG+GG) & & & & 0.638 \\
\hline Recessive (CC+CG vs. GG) & & & & 0.180 \\
\hline \multicolumn{5}{|l|}{$\operatorname{miR}-149 \mathrm{~T}>\mathrm{C}$} \\
\hline$\pi$ & $41(45.1)$ & $20(54.1)$ & 12 (37.5) & 0.382 \\
\hline TC & $42(46.2)$ & $16(43.2)$ & 18 (56.3) & 0.518 \\
\hline $\mathrm{CC}$ & 8 (8.8) & $1(2.7)$ & $2(6.3)$ & 0.461 \\
\hline Dominant (TT vs. $T C+C C)$ & & & & 0.382 \\
\hline Recessive (T+TC vs. CC) & & & & 0.461 \\
\hline \multicolumn{5}{|l|}{ miR-196a2T>C } \\
\hline$\pi$ & $25(27.5)$ & $8(21.6)$ & $12(37.5)$ & 0.335 \\
\hline TC & $44(48.4)$ & $17(45.9)$ & 12 (37.5) & 0.570 \\
\hline $\mathrm{CC}$ & $22(24.2)$ & $12(32.4)$ & $8(25.0)$ & 0.619 \\
\hline Dominant (TT vs. TC+CC) & & & & 0.335 \\
\hline Recessive (T+TC vs. CC) & & & & 0.619 \\
\hline \multicolumn{5}{|l|}{$m i R-499 A>G$} \\
\hline AA & $60(65.9)$ & $24(64.9)$ & $16(50.0)$ & 0.262 \\
\hline$A G$ & $30(33.0)$ & $13(35.1)$ & 15 (46.9) & 0.367 \\
\hline GG & $1(1.1)$ & $0(0.0)$ & $1(3.1)$ & 0.512 \\
\hline Dominant (AAvs. AG+GG) & & & & 0.262 \\
\hline Recessive (AA+AG vs. GG) & & & & 0.512 \\
\hline
\end{tabular}

도가 낮은 점이 특이했으나 전반적으로 암의 분화도에 따른 차이 는 없었다 (Table 4).

\section{5. 암의 장벽 침윤도에 따른 miRNA 유전자 다양성}

조직학적 장벽 침윤도 T1: 11예, T2: 19예, T3: 93예, T4: 37예 에 따른 4 가지 miRNA 유전자 다양성의 분포를 보았다. 여기서 도 비슷하게 $\mathrm{miR}-196 \mathrm{a} 2 \mathrm{~T}>\mathrm{C}$ 에서 4 단계 침윤도 모두에서 우성 동형 유전자 $\mathrm{TT}$ 의 낮은 분포도를 보였으나, 전반적인 침윤도에 따른 4가지 miRNA 유전자 다양성의 분포 차이는 없었다 (Table 5).

\section{6. 국소 림프절 전이에 따른 miRNA 유전자 다양성}

국소 림프절 전이 정도 N0: 91예, N1: 37예, N2: 32예 에 따른 4 가지 miRNA 유전자 다양성의 분포를 살펴 보았으나 지극히 고른 분포로 역시 의미있는 차이를 발견할 수 없었다 (Table 6) .

\section{고 찰}

MicroRNA 종류와 여러 암과의 관계는 서론에서 기술한 바와 같 으나 암의 진행 정도와 miRNA 사이의 연구보고는 아직 많지 않 은데 Arndt 등이는 대장암 세포주 실험에서 여러 miRNAs 중에 서 특히 miR-145의 발현이 전이성 대장암 세포주에서 뚜렷이 감소됨을 발견하여 대장암의 전이와 연관성에 대해 언급하였고, Scepeler 등 ${ }^{21}$ 은 miR-145의 감소가 대장암의 공격성 (aggressiveness)과 관련 있다고 보고하였다. Slaby 등른 은 몇가 지 miRNAs의 실험에서 miRMA-21의 발현 증가가 국소 림프절 및 원격전이 와 관련이 있음을 보고하였고, Bandres 등 ${ }^{23}$ 도 $\mathrm{miR}-31$ 의 증가가 대장암의 병기와 연관이 있다고 보고하였다. MicroRNAs 발현의 증가 혹은 감소 뿐만 아니라 유전자 다양성 (polymorphism)에 따른 각종 암과의 관계를 연구한 논문들이 발표되고 있다. 예를 들어 Hoffman등 ${ }^{24}$ 은 miR-196a2의 C 대립 유전자(allele)가 의미있게 유방암과의 관련성이 있다고 보고하였 고, Tian 등 ${ }^{25)}$ 은 miR-196a2의 CC 유전자 형이 중국인들에서 뚜렷하게 폐암과의 위험성을 증가시킨다고 보고하였다. $\mathrm{miR}-$ $146 \mathrm{a}$ 의 경우 $\mathrm{Guo}$ 등 26 은 $\mathrm{GG}$ 변이 유전자형(genotype)이 의미 있 게 중국인들에서 식도암의 위험도를 증가시킨다고 보고하였고 Jazdzewski등 ${ }^{27}$ 은 miR-146a의 CG형이 갑상선 암의 위험도와 관련 있다고 보고하였다.

그런데 microRNAs의 유전자 다양성(polymorphism)에 따른 대 장암 진행 정도와의 관계를 연구한 논문은 매우 드물다. 따라서 miRNA 유전자 다양성과 대장암에 대한, 특히 대장암의 진행 정 도와의 연관성 연구로는 본 논문이 국내 보고로는 선행적 의의를 지닌다고 생각된다. 본 연구에서는 위에서 언급한 타 암에서의 연관성이 보고되고, 또 본 연구자들이 선택 가능했던 4 가지 이 들 miRNA : miR-146a C>G, miR-149 C>T, miR-196a2 C>T 와 miR-499 A>G의 유전자 다양성이 암 병기, 장벽 침윤도, 국 소 림프절 전이 등의 대장암의 진행 정도를 나타내는 임상요소들 에 따라 어떻게 변화 있게 나타나는 지를 본 것이다. 아울러 이 들 중 일부는 아직 대장암과의 연관성이 보고되어 있지 않은데, 현재 세계 각처에서 다양한 $\mathrm{mRNA}$ 를 이용하여 각종 암과의 관 계를 밝히려 시도를 하고 있어 본 연구도 그 일환으로서의 의미 가 있다고 하겠다. 또한 본 연구자들은 대조군 건강집단에서의 이 들 miRNA의 유전자 다양성과 대장암 환자들에서의 다양성 차이에 따른 발병, 예후 및 생존율 등을 비교 분석할 장기적인 실 험을 현재 진행하고 있어, 본 논문은 mRNA에 대한 소개와 암의 임상적 진행양상과의 일면적인 관계를 보는 선별적인 논문으로 
서 성격을 지닌다고 할 수 있다. 따라서 대조군 건강집단에서의 이들 miRNA의 유전자 다양성의 분포는 본 논문 목적에 직접적 인 관련이 없어 언급하지 않았다. 실험결과로, 먼저 이들 miRNA 의 유전자형의 분포가 성별과 결장, 직장의 암의 위치 등 기본적 인 임상 요소에 따라 어떻게 나타나는지를 보기 위해 그 분포를 보았으나 각 두 그룹간의 차이가 없었다. 다만 대부분 miRNA의 이형접합성(heterozygous) 유전자 조합이 다수의 빈도를 차지하 였으나 miR-499A>G에서만 이 우성 동형 AA 유전자가 다수의 빈도를 보였다. 암의 임상적 진행 요소들과의 4 가지 miRNA 유 전자 다양성의 의미 있는 분포의 변화를 예견하였으나 기대에 못 미치게 병기, 장벽 침윤도, 국소 림프절 전이 및 암의 분화도의 어느 요소에서도 의미 있는 변화를 발견할 수 없었다. 이러한 결 과는 Chen 등 ${ }^{28}$ 이 보고한 중국인 대장암 환자에서의 $\mathrm{miR}-$ $196 \mathrm{a} 2$ 의 CC 변이형이 대장암에로의 위험도나 대장암의 진행과 무관하다는 것과 유사하다. 다만 $\mathrm{miR}-196 \mathrm{a} 2 \mathrm{C}>\mathrm{T}$ 가 여러 요소 들에서도 우성 동형 유전자 TT의 낮은 분포도를 보이는 것이 눈에 띠는 정도였다. 그러나 괄목할만한 의미는 없어도 이러한 점들을 깊이 연구하다 보면 micro RNA 및 그 유전자 다양성이 각종 암의 발암 및 진행에 관여하는 역할을 밝히는데 도움이 될 것이다.

\section{결 론}

본 실험에서 선택한 4 가지 miRNA의 유전자 다양성이 대장암의 임상적 진행 정도에 따라 의미 있는 결과를 보이진 않았지만 앞 으로 대장암을 비롯한 각종 암에서 miRNA와의 관계 및 역할을 밝히도록 보다 다양한 많은 연구가 이루어져야 할 것이다.

\section{REFERENCES}

1. Garzon R, Fabbri M, Cimmino A, Calin GA, Croce CM. MicroRNA expression and function in cancer. Trends in Molecular Medicine 2006;12:580-587.

2. Sassen S, Miska EA, Caldas C. MicroRNA-implications for cancer. Virchows Arch 2008;452:1-10.

3. Bartel DP. MicroRNAs: target recognition and regulatory functions. Cell 2009;136:215-233.

4. Lim LP, Lau NC, Garrett-Engele $P$, et al. Microarray analysis shows that some microRNAs downregulate large numbers of target mRNAs. Nature 2005;433:769-773.

5. Wilfred BR, Wang WX, Nelson PT. Energizing miRNA research: a review of the role of miRNAs in lipid metabolism, with a prediction that miR-103/107 regulates human metabolic pathways. Mol Genet Metab 2007;91:209-217.

6. Rodriguez A, Griffiths-Jones S, Ashurst JL, Bradley A. Identification of mammalian microRNA host genes and transcription units. Genome Res 2004;14:1902-1910.

7. Lee $Y$, Kim M, Han J, et al. MicroRNA genes are transcribed by RNA polymerase II. EMBO J 2004;23:4051-4060.

8. Gregory RI, Chendrimada TP, Shiekhattar R. MicroRNA biogenesis: isolation and characterization of the microprocessor complex. Methods Mol Biol 2006;342:33-47.

9. Calin GA, Dumitru CD, Shimizu M, et al. Frequent deletions and down-regulation microRNA genes miR 15 and miR 16 at $13 q 14$ in chronic lymphocytic leukemia. Proc Natl Acad Sci 2002;99:15524-15529.

10. Takamizawa J, Konishi $H$, Yanagisawa K, et al. Reduced expression of the let-7 microRNA in human lung cancers in association with shortened postoperative survival. Cancer Res 2005;64:3753-3756.

11. Eis PS, Tam W, Sun $L$, et al. Accumulation of miR-155 and BIC RNA in human B cell lymphomas. Proc Natl Acad Sci 2005;103:3627-3632.

12. Irio $M V$, Ferracin $M$, Liu CG, et al. microRNA gene expression deregulation in human breast cancer. Cancer Res 2005;65:7065-7070.

13. Michael MZ, O' Connor SM, Pellekaan NG, Young GP, James RJ. Reduced accumulation of specific microRNAs in colorectal neoplasia. Mol Cancer Res 2003;1:882-891.

14. Schimanski CC, Frerichs $K$, Rahman $F$, Berger $M$, Lang $H$, Galle PR, et al. High pre-miR-196a levels promote the oncogenic phenotype of colorectal cancer cells. World J Gastroenterol 2009;15:2089-2096.

15. Hu Z, Chen J, Tian T, Zhou $X, G u$ H, Zeng $Y$, et al. Genetic variants of miRNA sequences and non-small cell lung cancer survival. J Clin Invest 2008;118:2600-2608.

16. Oi $P$, Dou TH, Geng L, Zhou FG, Gu X, Wang $H$, et al. Association of a variant in MIR 196A2 with susceptibility to hepatocellular carcinoma in male Chinese patients with chronic hepatitis B virus infection. Hum Immunol 2010;71:621-626.

17. Peng S, Kung Z, Sheng $C$, Zhang $Y$, Zum H, Cheng $Q$. Association of microRNA-196a2 gene polymorphism with gastric cancer risk in a Chinese population. Dig Dis Sci 2009;55:2288-2293. 18. Hu Z, Liang J, Wang Z, Tian T, Zhou $X$, Chen J, et al. Common genetic variants in pre-microRNAs were associated with increased risk of breast cancer in Chinese women. Hum Mutat 2009;30: 79-84. 19. Guo $H$, Wang $K$, Xiong G, Hu H, Wang $D$, Xu $X$, et al. A functional variant in microRNA-146a is associated with risk of esophageal squamous cell carcinoma in Chinese Han. Familial Cancer 2010;9:599-603. 
20. Arndt GM, Dossey $L$, Cullen $L M$, Lai $A$, Drunker $R$, Eisbacher $M$, et al. Characteristics of global microRNA expression reveals oncogenic potential of miR-145 in metastatic colorectal cancer. BMC Cancer 2009;9:374-390.

21. Scepeler T, Reinert JT, Ostenfeld MS, Christensen LL, Silahtaroglu AN, Dyrskot $L$, et al. Diagnostic and prognostic MicroRNAs in Stage II Colon Cancer. Cancer Res 2008;68: 6416-6424.

22. Slaby $O$, Svoboda $M$, Fabian $P$, Smerdova $T$, Knoflickova $D$, Bednarikova $\mathrm{M}$, et al. Altered expression of miR-21, miR-31, miR143 and miR-145 id related to clinicopathologic features of colorectal cancer. Oncology 2007;72:397-402.

23. Bandres $E$, Cubedo $E$, Agirre $X$, Malumbres $R$, Zarate $R$, Ramirez $N$, et al. Identification by real-time PCR of 13 mature microRNAs differentially expressed in colorectal cancer and nontumoral tissues. Molecular Cancer 2006;5:29-38.

24. Hoffman $A E$, Zheng $T$, Yi $C$, Leaderer $D$, Weidhaas J, Slack $F$, et al. microRNA miR-196a-2 and breast cancer: a genetic and epigenetic association study and functional analysis. Cancer Res 2009;69:5970-5977.

25. Tian $T$, Shu $Y$, Chen J, Hu Z, Xu L, Jin G, et al. A functional genetic variant in microRNA-196a2 is associated with increased susceptibility of lung cancer in Chinese. Cancer Epidemiol Bi37omarkers Prev 2009;18:1183-1187.

26. Guo $H$, Wang $K$, Xiong G, Hu H, Wang D, Xu X, et al. A functional variant in microRNA-146a is associated with risk of esophageal squamous cell carcinoma in Chinese Han. Familial Cancer 2010;9:599-603.

27. Jazdzewski K, Murray EL, Franssila K, Jarzab B, Schoenberg DR, Chapelle ADL. Common SNP in pre-miR-146a decreases mature miR expression and predisposes to papillary thyroid carcinoma. Proc Natl Acad Sci 2008;105:7269-7274.

28. Chen $H$, Sun $L Y$, Chen LL, Zheng HQ, Zhang QF. A variant in microRNA-196a2 is not associated with susceptibility to and progression of colorectal cancer in Chinese. Intern Med J 2011;17. DOI: 10.1111/j.1445-5994.2011.02434.x. 


\section{The Relationship between the progression of colorectal cancer and microRNA polymorphisms}

Department of Surgery, 'Institute for Clinical Research „, School of Medicine, CHA University, Seongnam, South Korea Ho Jin Chang, Nam Keun Kim', Young Joo Jeon', Jong Woo Kim

\section{Abstract}

Purpose : MicroRNA(miRNA) is related not only with basic biologic process but with regulatory functions of diverse diseases including cancer. Although it is non-coding RNA of small nucleotides(18 23), nucleotide variation within primary(pri)- or precursor(pre)-miRNA might affect the mature process of miRNA and can cange it. And then we aim to elucidate the relationship between 4 kinds of pre-miRNA and clinical progress of colorectal cancer such as tumor stage, depth of invasion and regional lymph nodes metastasis.

Methods : DNA was extracted from blood samples of 160 patients who underwent operation on colorectal cancers during recent 2 years and has-mir-146aC $>G$, has-mir-149T>C, has-mir-196a2T>C and has-mir-499A $>G$ polymorphisams were genotyped by PCR-RFLP.

Results : There was no relationship between the polymorphism distributions of 4 kinds of pre-miRNA and any clinical progresses of colorectal cancer.

Conclusion : Although we were unable to find out significant relation between two categories, further active studies with miRNAs and cancers shoud be carried on.

Key Words : MicroRNA, polymorphism, Colorectal cancer

Correspondence : Jong Woo Kim

Department of Surgery, School of Medicine, CHA University, 351, Yatap-dong, Bundang-gu, Seongnam-si, 463-712, South Korea Tel: 82-31-780-5250 Fax: 82-31-780-5259 E-mail: kjw@cha.ac.kr

Received : September 23, 2011 ; Accepted : October 20, 2011 